Pujiyati, Prabang Setyono, Wiryanto. (2019). Risiko Pemanfaatan Air Baku Pokmair Watumalang melalui Tinjauan Cemaran Koliform. Journal Bioeksperimen. Vol. 5 (2) Pp. 77-86. Doi: 10.23917/bioeksperimen.v5i2.2795

\title{
RISIKO PEMANFAATAN AIR BAKU POKMAIR WATUMALANG MELALUI TINJAUAN CEMARAN KOLIFORM
}

\author{
Pujiyati*, Prabang Setyono, Wiryanto \\ Magister Ilmu Lingkungan Universitas Sebelas Maret Surakarta \\ *Email korespondensi : ${ }^{1}$ pujiyati.zara@gmail.com \\ Paper diterima : 5 Juni 2017 \\ Paper terbit : September 2019
}

\begin{abstract}
Watumalang, Wonosobo, is a district with substantial spring utilization (60.66\%). Limited management in quality of water utilization is considered a risk to health, especially from coliform contamination. The purpose of this study is to assess the risk of using raw water of POKMAIR group (spring users), specifically from the coliform aspect. The study was conducted primarily by water sampling and respondent questionnaires. Data analysis was performed descriptively and correlatively. The result shows that $71 \%$ of water samples did not meet the requirements as clean water from the coliform aspect. Utilization risk assessment shows that $37.5 \%$ of high-risk villages. Further analysis shows that the closest relationship to coliform was the ownership of sanitation facilities $(r-0,381)$.
\end{abstract}

Keywords: water quality, coliform, utilization, Watumalang

\section{Pendahuluan}

Air bersih merupakan sumber daya dengan keterbatasan pada kuantitas dan kualitas, memiliki tren terus menurun akibat pertumbuhan populasi, urbanisasi dan perubahan iklim (Mohsin et al., 2013). Avigliano dan Schenone (2015) menjelaskan bahwa faktor pembatas pemanfaatan air adalah oleh pencemaran antropogenik. Risiko pencemaran lebih tinggi pada air permukaan atau air yang ditempatkan pada permukaan. Hal ini menjadikan pengelolaan air menjadi permasalahan lingkungan global terkait dengan keberlanjutan, pengelolaan dan konservasi (Avans et al., 2012 dalam Soeprobowati et al., 2016).

Saat ini, WHO melaporkan bahwa lebih dari $80 \%$ temuan penyakit pada masyarakat merupakan waterborne disease. Sebagian besar terjadi di negara berkembang. Total koliform secara umum tidak menyebabkan penyakit, melainkan sebagai indikator. Beberapa strain dari Eschericia coli (sebagai bagian umum kelompok koliform) diketahui mampu menimbulkan penyakit pada manusia, seperti E.coli 0157:H7. Keberadaan koliform seperti E.coli mengindikasikan adanya patogen penyebab penyakit pada air seperti bakteri, virus dan parasit (Pal, 2014).

Megha et al. (2015) mendeskripsikan dua mekanisme utama pencemaran air yaitu ketidaksempurnaan distribusi dan rendahnya kesadaran individu memenuhi syarat higienis. Aspek pencemaran ditinjau salah satunya dari cemaran koliform. Kelompok ini merupakan indikator cemaran tinja karena habitat idealnya adalah pada intestinal hewan berdarah panas, meski dapat pula ditemukan secara alami (Campbell et al., 2011).

Cemaran fekal koliform adalah indikasi ancaman nyata kesehatan masyarakat dengan potensi menimbulkan beragam wabah penyakit dari penggunaan air sesuai dengan kesimpulan penelitian Butt and Ghaffar (2015). Eksistensinya dapat pula dipengaruhi oleh faktor musim dengan kecenderungan memiliki daya tahan yang tinggi terhadap perubahan lingkungan (Conclasure et al., 2015). 
Penelitian sebelumnya oleh Pujiyati et al. (2016) menunjukkan pemanfaatan mata air sebagai air baku masyarakat POKMAIR di Watumalang memiliki risiko tinggi pada cemaran koliform. Hampir keseluruhan sampel air uji tidak memenuhi syarat terutama sebagai air minum. Salah satu penyebabnya adalah risiko pencemaran sarana yang tinggi pada beberapa desa. Mempertimbangkan tingginya rasio pemanfaatan sumber air tersebut $(60,66 \%)$ di Watumalang, maka kondisi ini memprihatinkan dan berisiko pada kesehatan masyarakat. Terjadinya kejadian luar biasa (KLB) pada beberapa desa di tahun sebelumnya dapat menjadi indikasi dampak kesehatan tersebut.

Tujuan penelitian ini adalah menilai dan mengkaji risiko pemanfaatan mata air sebagai sumber air baku masyarakat POKMAIR di Kecamatan Watumalang, terutama ditinjau dari cemaran koliform dan aspek aspek yang dianggap berkorelasi dengan peningkatan nilainya.

\section{Metode Penelitian}

\section{Lokasi dan Waktu Penelitian}

Lokasi penelitian adalah Kecamatan Watumalang, Wonosobo yang terbagi menjadi 16 desa dengan masing masing direpresentasikan dalam penelitian ini. Waktu penelitian adalah bulan November 2016 - Januari 2017. Uji MPN dilaksanakan di Laboratorium Dinas Kesehatan Kabupaten Wonosobo.

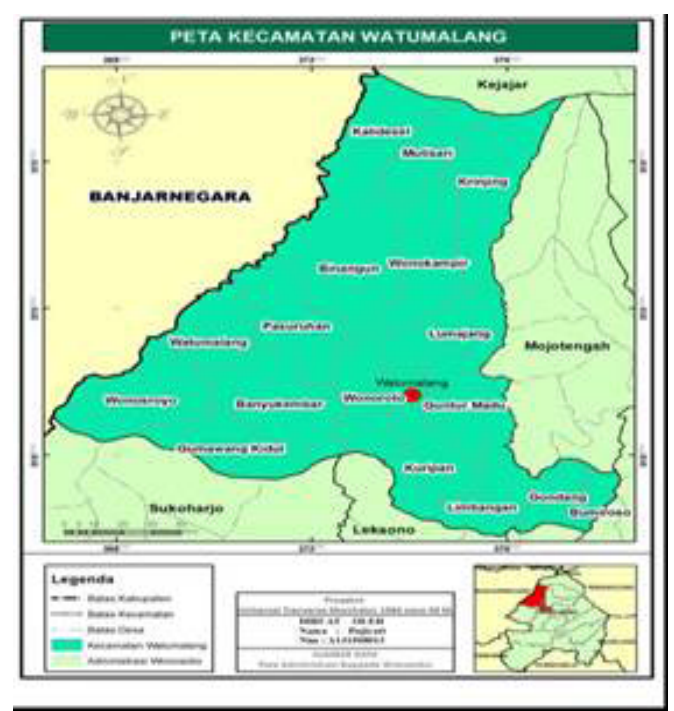

Gambar 1. Lokasi penelitian, Kecamatan Watumalang

\section{Alat dan bahan}

Alat yang digunakan dalam penelitian ini adalah set sampling bakteriologis, ice pack, botol flakon steril, set analisis MPN, alat tulis, lembar kuisioner dan laptop/komputer dilengkapi dengan Microsoft Office dan SPSS 20. Bahan yang dimanfaatkan dalam penelitian ini adalah sampel air (untuk keperluan uji MPN), set kemikalia uji MPN, hasil kuisioner dan data sekunder pemerintah.

\section{Koleksi data}

Sampel air diambil dan masing-masing mewakili setiap desa di Kecamatan Watumalang (51 sampel). Kuisioner diambil dari responden yang berdomisili di Kecamatan Watumalang (mewakili setiap desa) dan merupakan anggota masyarakat POKMAIR. Jumlah total responden kuisioner adalah 205 responden. Data sekunder digunakan sebagai pendukung pembahasan penelitian ini dikumpulkan dari dokumen resmi pemerintah terkait dengan bahasan dalam penelitian ini.

\section{Analisis data}

Variabel utama dalam penelitian ini adalah cemaran koliform (y) hasil analisis MPN dari sampel air Kecamatan Watumalang. Variabel tersebut dikelompokkan secara nominal (Tabel $1)$.

Tabel 1. Penentuan kategori dan nilai nominal cemaran koliform

\begin{tabular}{ccc}
\hline Nilai MPN & Kategori & Nominal \\
\hline $0-49$ & A & 5 \\
$50-99$ & B & 4 \\
$100-1000$ & C & 3 \\
$1000-2400$ & D & 2 \\
$>2400$ & E & 1 \\
\hline
\end{tabular}

Nilai nominal berfungsi dalam menentukan rata-rata nilai setiap desa. Variabel lainnya adalah hasil dari kuisioner terhadap masyarakat POKMAIR terkait persepsi lingkungan $\left(\mathrm{x}_{1}\right)$ dan kepemilikan sanitasi $\left(\mathrm{x}_{2}\right)$ serta penilaian terhadap risiko pencemaran sarana $\left(\mathrm{x}_{3}\right)$. Kuisioner tentang persepsi lingkungan dan

78-Resiko Pemanfaatan Air... 
kepemilikan sarana sanitasi terlebih dahulu diuji melalui validitas dan relaiabilitas dengan SPSS 20 dan menghasilkan nilai koefisien Cronbach Alpha 0,960 (reliabel). Berikut adalah kategori penilaian untuk kuisioner persepsi lingkungan dan kepemilikan sarana sanitasi. Penilaian terhadap risiko pencemaran sarana dilakukan menggunakan kuisioner baku dari Kementerian Kesehatan Republik Indonesia.

Penilaian terhadap risiko pemanfaatan mata air sebagai air baku masyarakat POKMAIR dilakukan dengan skoring terhadap variabelvariabel di atas (cemaran koliform, persepsi lingkungan, kepemilikan sarana sanitasi dan resiko pencemaran sarana) ditambah dengan rasio pemanfaatan setiap desa. Rasio pemanfaat berisiko pada potensi terjadinya KLB waterborne disease akibat tidak terkendalinya kualitas air baku. Berikut adalah model skoring dalam penelitian ini.

Tabel 2. Kategori penilaian kuisioner persepsi lingkungan dan kepemilikan sarana sanitasi

\begin{tabular}{|c|c|c|c|c|c|}
\hline \multicolumn{3}{|c|}{ Persepsi Lingkungan } & \multicolumn{3}{|c|}{$\begin{array}{c}\text { Kepemilikan Sarana } \\
\text { Sanitasi }\end{array}$} \\
\hline 㫄 & ‡: & ڤే & 㫄 & z: & है \\
\hline $96-102$ & A & Sangat baik & $8-9$ & $\mathrm{~A}$ & Baik \\
\hline $89-95$ & $\mathrm{~B}$ & Baik & $6-7$ & B & Cukup \\
\hline $82-88$ & $\mathrm{C}$ & Sedang & $4-5$ & $\mathrm{C}$ & Kurang \\
\hline $74-81$ & $\mathrm{D}$ & Buruk & $<3$ & $\mathrm{D}$ & $\begin{array}{l}\text { Sangat } \\
\text { Buruk }\end{array}$ \\
\hline$<74$ & $\mathrm{E}$ & $\begin{array}{l}\text { Sangat } \\
\text { Buruk }\end{array}$ & & & \\
\hline
\end{tabular}

Tabel 3. Skoring penilaian risiko pemanfaatan air baku pada masing-masing variabel Rentang Nilai Pada Kategori Penilaian

\begin{tabular}{|c|c|c|c|c|c|}
\hline & 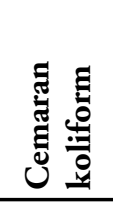 & 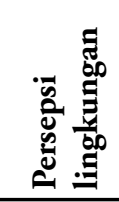 & శ్ & 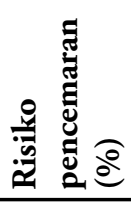 & •월 \\
\hline 1 & $4,6-5$ & $96-102$ & $8-9$ & $0-19$ & $0-19$ \\
\hline 2 & $3,6-4,5$ & 89-95 & $6-7$ & $20-39$ & $20-39$ \\
\hline 3 & $2,6-3,5$ & $82-88$ & $4-5$ & $40-59$ & $40-59$ \\
\hline 4 & $1,6-2,5$ & $74-81$ & $2-3$ & $60-79$ & $60-79$ \\
\hline 5 & $1-1,5$ & $<73$ & 1 & $80-100$ & $80-100$ \\
\hline
\end{tabular}

Analisis dilakukan secara deskriptif kuantitatif dan kualitatif. Analisis kuantitatif melalui skoring hasil penelitian dan statistik korelasi Pearson untuk menilai hubungan antara variabel cemaran koliform dengan persepsi lingkungan, kepemilikan sarana sanitasi dan risiko pencemaran sarana. Analisis korelasi akan menunjukkan variabel yang berhubungan erat dengan cemaran koliform pada air baku POKMAIR di Kecamatan Watumalang. Untuk penilaian risiko pemanfaatan air baku POKMAIR setiap desa menggunakan ketentuan sebagai berikut :

Tabel 4. Kategori risiko pemanfaatan setiap desa

\begin{tabular}{cl}
\hline $\begin{array}{c}\text { Nilai Total } \\
\text { (per desa) }\end{array}$ & \multicolumn{1}{c}{ Keterangan } \\
\hline $5-7$ & Risiko Sangat Rendah \\
$7-9$ & Risiko Rendah \\
$10-14$ & Risiko Sedang \\
$15-19$ & Risiko Tinggi \\
$20-25$ & Risiko Sangat Tinggi \\
\hline
\end{tabular}

\section{Hasil dan Pembahasan}

Watumalang adalah salah satu kecamatan di Wonosobo dengan penciri agraris nonsawah. Data penggunaan lahan menunjukkan luas lahan sawah di Watumalang mencapai $511,485 \mathrm{Ha}(7,49 \%)$ dan non sawah 6311,427 Ha (92,50\%). Jumlah penduduk Kecamatan Watumalang berdasarkan survey penduduk BPSD Wonosobo pada tahun 2015 adalah 49266 jiwa. Pada tahun yang sama, rasio kepadatan penduduk Watumalang adalah 722 jiwa $/ \mathrm{km}^{2}$.

Dokumen Data dan Informasi Lingkungan Hidup Jawa Tengah (2015) mendeskripsikan hanya $15,09 \%$ sampah domestik terangkut hingga tempat pembuangan akhir (TPA). Sebagian sampah domestik dikelola mandiri dengan pembakaran (open burning) atau dikubur (36,23\%). Ironisnya, 21,51\% sampah dibiarkan menumpuk (open dumping) atau dibuang di badan air (sungai, saluran irigasi dan selokan). 


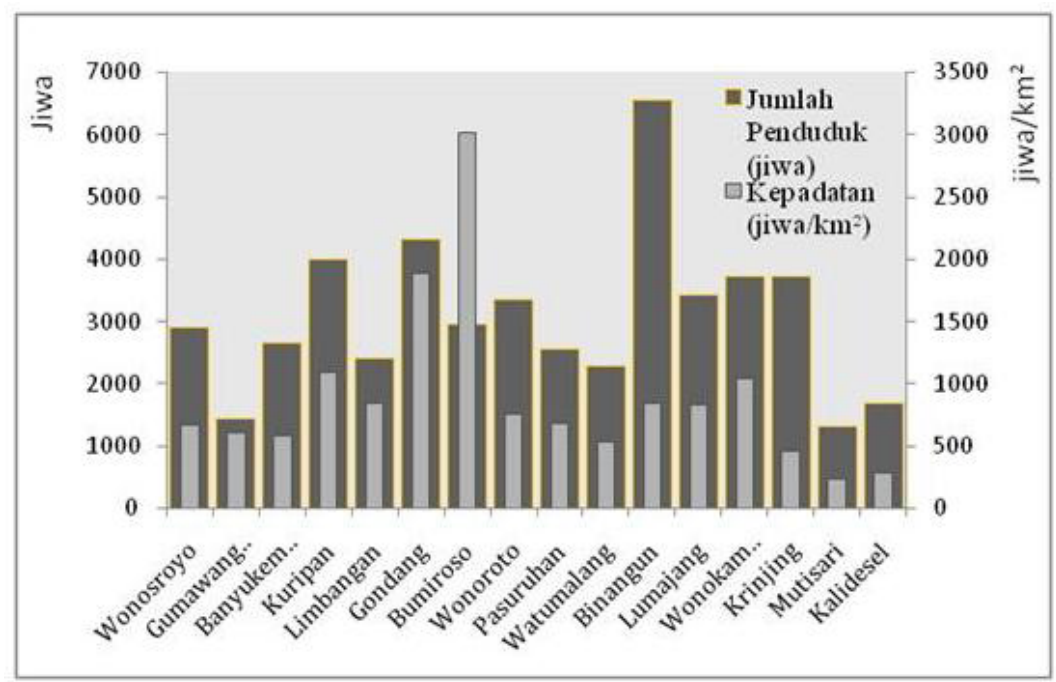

Gambar 2. Jumlah dan kepadatan penduduk Watumalang (sumber : Data BPS (2016) diolah)

Sebesar $66,04 \%$ penduduk desa di Wonosobo mengandalkan mata air sebagai air baku dan sisanya memanfaatkan air ledeng dari Perusahaan Air Minum (PAM) maupun air kemasan (BPSP Jawa Tengah, 2016). BPSP Jawa Tengah (2015) mengindikasikan terdapat $25 \%$ warga yang tidak memiliki jamban mandiri dan lebih dari $80 \%$ masyarakat memiliki tipe penampungan tinja non septic tank. Kepemilikan sistem pengolahan air limbah (SPAL) domestik juga menjadi fasilitas langka (17\%). Angka kepemilikan jamban, septic tank dan SPAL masyarakat Wonosobo adalah terendah di Provinsi Jawa Tengah

Kabupaten Wonosobo menduduki peringkat ke 34 dari 35 kabupaten di Jawa Tengah untuk cakupan jamban sehat dengan persentase $\quad 50,16 \%$ (Dinas Kesehatan Kabupaten Wonosobo, 2013). Data Sanitasi Total Berbasis Masyarakat (2016) menunjukkan akses jamban di Kecamatan Watumalang adalah 64,78\%. Dari keseluruhan 14.878 KK, hanya $4864 \mathrm{KK}$ yang telah memiliki jamban permanen. Sejumlah 4639 KK $(31,18 \%)$ tidak terakses jamban atau tidak memiliki sarana sanitasi baik secara pribadi maupun bersama.
Sisanya memiliki jamban semi permanen dan menggunakan jamban bersama.

\section{Deskripsi hasil penelitian}

Data kesehatan lingkungan dan sanitasi tersebut mengindikasikan potensi permasalahan pada kualitas air akibat minimnya kualitas sarana sanitasi, termasuk di Watumalang. Kekurangan dalam pola dan sarana akan berdampak pada risiko cemaran terutama oleh koliform. Berikut adalah hasil evaluasi cemaran koliform di Watumalang.

Watumalang memiliki pengguna mata air lebih dari separuh penduduknya (60,66\%). Gambar 3 menunjukkan hanya 2 desa (Gondang dan Limbangan) yang dianggap mampu memenuhi kualitas sebagai air bersih atau setara 29\% (sesuai Permenkes 416 Tahun 1990). Angka yang ironis karena pada kedua desa tersebut rasio pemanfaatan mata air rendah $(<20 \%)$. Adapun beberapa desa memiliki cemara koliform tinggi dengan rasio pemanfaatan juga tinggi seperti Wonosroyo dan Watumalang (>70\%). Hal ini menggambarkan tingginya resiko terjadinya waterborne disease pada lokasi tersebut. 


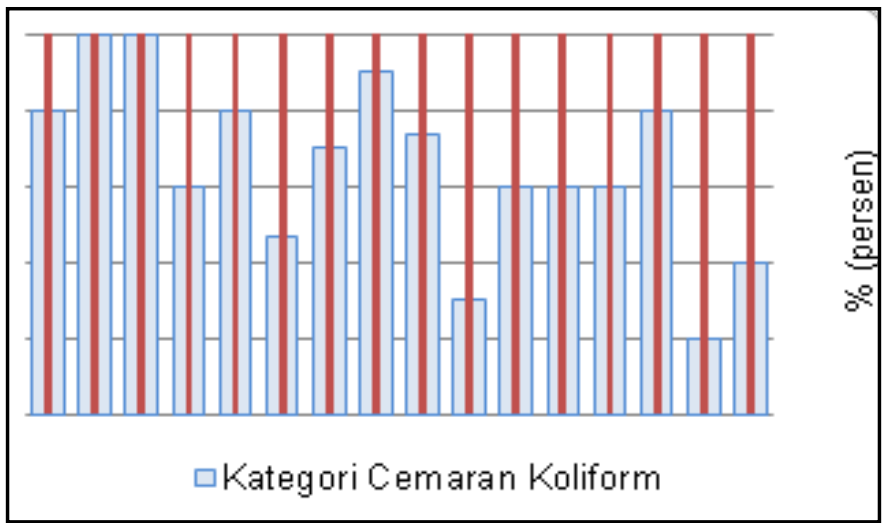

Gambar 3. Perbandingan cemaran koliform dan rasio pemanfaatan setiap desa di Watumalang (sumber : data primer diolah, 2016)

Dendrogram pada gambar 3 menggambarkan tingginya resiko terjadinya waterborne disease pada lokasi tersebut. Adanya perbedaan signifikan antara garis menunjukkan rasio pemanfaatan dan cemaran koliform, terutama ketika cemaran koliform jauh melampaui rasio pemanfaatan, menunjukkan ketimpangan antara kebutuhan pemanfaatan dengan kemampuan untuk mengelola kualitas air, khususnya pada variabel cemaran koliform.

Laporan dari Dinas Kesehatan pada periode pemantauan 2015-2016 menunjukkan diare bukan penyakit dominan. Meski demikian ancaman penyakit diare berpotensi terjadi dengan pertimbangan eksistensi koliform yang tinggi (Butt and Ghaffar, 2015). Selain itu, angka penurunan peristiwa diare pada periode tersebut tidak signifikan (sig 0,316) menggambarkan rendahnya upaya mitigasi peristiwa ini. Berkombinasi dengan permasalahan kesehatan lingkungan lain, termasuk cemaran koliform pada air baku, maka KLB diare bisa saja terjadi ketika kesadaran dan mitigasi pihak terkait lemah.

Persepsi lingkungan, kepemilikan sarana sanitasi dan risiko pencemaran sarana merupakan tiga variabel lain yang dianggap memiliki hubungan dengan terjadinya cemarann koliform pada air baku POKMAIR Watumalang. Dua variabel awal merupakan gambaran persepsi dan perilaku masyarakat pada penyediaan air baku.
Variabel terakhir berkaitan dengan kualitas sarana air bersih seperti perlindungan mata air dan reservoir yang memenuhi standar atau mempunyai faktor risiko cemaran yang rendah Persepsi lingkungan merupakan aspek yang dianggap telah merata dalam kondisi yang baik di Watumalang. Hal ini salah satu imbas upaya penyuluhan oleh instansi terkait hingga kemudahan aksesibilitas informasi melalui beragam media. Namun, persepsi yang telah baik tersebut nampaknya belum sepenuhnya muncul dalam perilaku masyarakat untuk mengelola kesehatan lingkungan. Kondisi ini digambarkan oleh kepemilikan sarana sanitasi yang tergolong terbatas, merata pada kategori penilaian kurang-cukup.

Nilai kurang pada kepemilikan sarana sanitasi mayoritas dikontribusikan pada instrumen kuisioner nomor 7 dan 8. Instrumen 7 terkait dengan kondisi tempat sampah (terbuka/ tertutup) dan instrumen 8 terkait jarak kandang dengan lokasi tampungan air. Keduanya menunjukkan keterbatasan masyarakat untuk melaksanakan tindakan sesuai persepsinya dengan salah satu pemnbatasnya adalah perekonomian. Hasil kuisioner sesuai dengan data BPSP Jawa Tengah mengenai permasalahan sampah secara umum di Kabupaten Wonosobo. Sarana sanitasi tersebut tersedia sebatas pemenuhan kuantitas namun belum memenuhi standar kualitas kelayakan. 


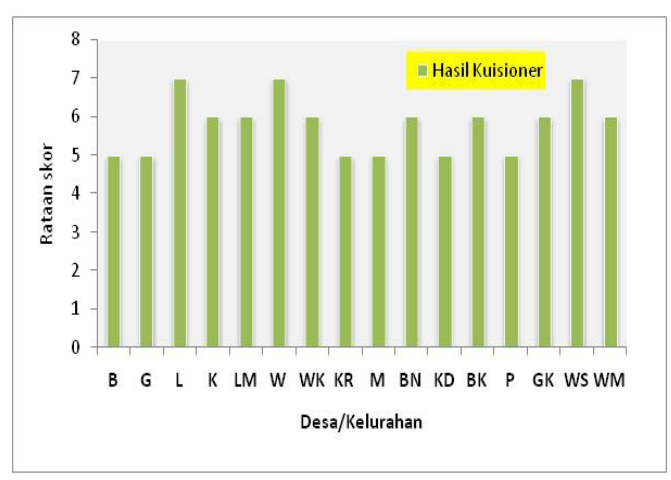

(a)

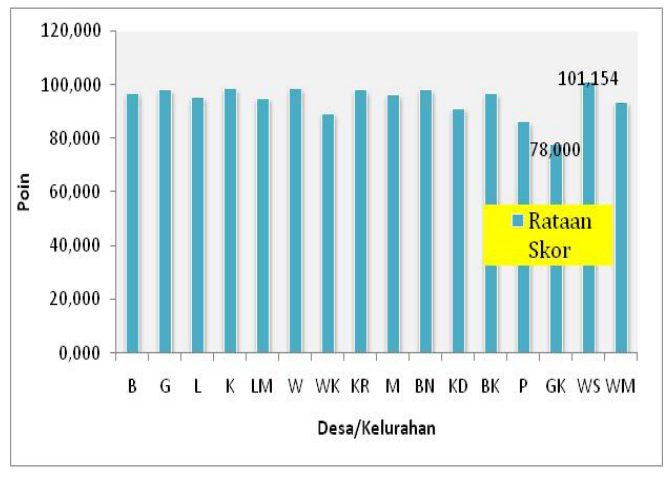

(b)

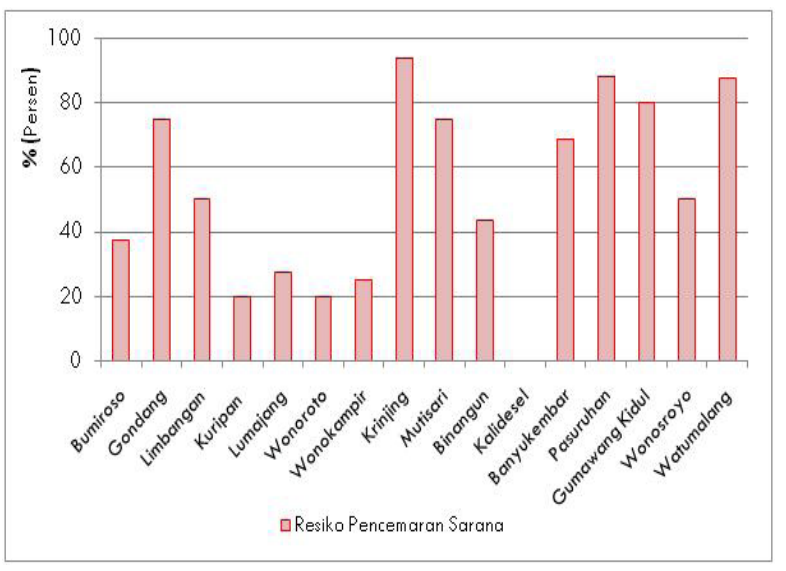

(c)

Gambar 4. Evaluasi kuisioner kepemilikan sarana sanitasi (a); persepsi lingkungan (b); dan risiko pencemaran sarana $(c)$

Situasi yang nyaris serupa tampak pada risiko pencemaran. Sarana yang dipantau seperti reservoir telah tersedia namun belum memenuhi persyaratan kualitas dan kelayakan kesehatan sehingga beberapa diantaranya dipandang berisiko tinggi pada pencemaran. Hasil pemantauan menunjukkan hanya $25 \%$ sarana yang dianggap rendah terhadap risiko pencemaran. Tingginya risiko pencemaran akan memudahkan kontaminasi beragam kontaminan (biologi, fisika dan kimia) pada air baku.

\section{Hubungan antar variabel penelitian}

Analisis dengan aplikasi korelasi Pearson menggunakan software SPSS 20 memperoleh hasil sebagai berikut :

Tabel 4. Hasil uji korelasi Pearson untuk hubungan

\begin{tabular}{ccccc}
\multicolumn{5}{c}{ antar variabel } \\
\hline \multirow{2}{*}{ Var } & \multicolumn{4}{c}{ Korelasi Pearson (R) } \\
\cline { 2 - 5 } & $\mathbf{Y}$ & $\mathbf{x}_{1}$ & $\mathbf{x}_{2}$ & $\mathbf{x}_{3}$ \\
\hline $\mathrm{Y}$ & 1 & $-0,381$ & $-0,202$ & 0,186 \\
$\mathrm{x}_{1}$ & $-0,381$ & 1 & 0,173 & $-0,279$ \\
$\mathrm{x}_{2}$ & $-0,202$ & 0,173 & 1 & $-0,211$ \\
$\mathrm{x}_{3}$ & 0,186 & $-0,279$ & $-0,211$ & 1 \\
\hline
\end{tabular}

Sumber : pengolahan data primer (2016); Keterangan : $\mathrm{y}$ adalah kualitas air baku (koliform) komposit, $\mathrm{x}_{1}$ adalah kepemilikan sarana sanitasi, $x_{2}$ adalah persepsi kesehatan

lingkungan dan $\mathrm{x}_{3}$ adalah resiko pencemaran

Hasil pada Tabel 4 menunjukkan hubungan paling erat terhadap variabel y (cemaran koliform) adalah kepemilikan sarana sanitasi $(r-0,381)$. Semakin tinggi kepemilikan sarana sanitasi, kecenderungannya akan mampu menurunkan cemaran koliform pada air baku. Hasil ini sesuai dengan penelitian Tong et al., (2016) bahwa perbedaan kontaminasi koliform pada air baku disebabkan oleh perbedaan akses sanitasi sehat masyarakat. Aplikasi sanitasi sehat secara total diprediksi akan mengurangi $70 \%$ keseluruhan koliform fekal dalam air dan secara khusus akan menurunkan hingga 34\% koliform fekal yang dirilis oleh manusia.

Hasil menarik adalah korelasi yang sangat lemah antara persepsi dan kepemilikan sarana sanitasi $(0,173)$. Kondisi ini menunjukkan adanya batasan yang mengakibatkan persepsi lingkungan tidak terwujud dalam perilaku pada kasus Kecamatan Watumalang. Hal ini dapat diakibatkan oleh perekonomian, prioritas pembiayaan dan pendidikan masyarakat di 
Watumalang. Ekonomi pada skala rendah membuat aspek perbaikan kondisi kesehatan lingkungan menjadi prioritas akhir dibelakang pemenuhan kebutuhan primer sehari-hari. Meski demikian, persepsi lingkungan memiliki korelasi yang lebih kuat dengan cemaran koliform ( $\mathrm{r}-0,202)$ dan risiko pencemaran $(-0,211)$. Artinya, keterbatasan lebih mengarah pada perilaku yang berhubungan dengan pembangunan fasilitas sanitasi yang layak, nilai persepsi masih lebih baik pada perilaku berupa sikap sehari-hari untuk mengelola kesehatan lingkungan.

\section{Penilaian risiko pemanfaatan air baku POKMAIR di Watumalang}

Penilaian terhadap risiko pemanfaatan air baku yang bersumber dari mata air oleh masyarakat POKMAIR Kecamatan Watumalang dinilai dengan metode skoring berdasarkan hasil penelitian primer. Variabel yang dinilai meliputi cemaran koliform, kepemilikan sarana sanitasi, persepsi lingkungan, risiko pencemaran dan rasio pemanfaatan. Total skor diperoleh akan menggambarkan risiko pemanfaatan air baku tersebut pada masing-masing desa.

Tabel 5. Penilaian risiko pemanfaatan air baku POKMAIR di Watumalang

\begin{tabular}{|c|c|c|c|c|c|c|c|}
\hline Desa & 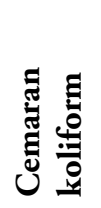 & 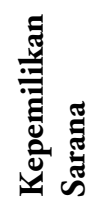 & 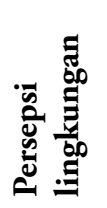 & 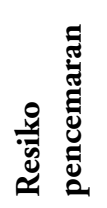 & ·욣 & $\frac{\ddot{0}}{\frac{3}{\pi}}$ & $\begin{array}{l}\text { Status risiko } \\
\text { pemanfaatan }\end{array}$ \\
\hline Bumiroso & 3 & 3 & 1 & 2 & 3 & 12 & Sedang \\
\hline Gondang & 2 & 3 & 1 & 4 & 1 & 11 & Sedang \\
\hline Limbangan & 1 & 2 & 1 & 2 & 2 & 8 & Rendah \\
\hline Kuripan & 4 & 2 & 1 & 2 & 3 & 12 & Sedang \\
\hline Lumajang & 2 & 2 & 2 & 2 & 4 & 12 & Sedang \\
\hline Wonoroto & 4 & 2 & 1 & 2 & 3 & 12 & Sedang \\
\hline Wonokampir & 3 & 2 & 2 & 2 & 4 & 13 & Sedang \\
\hline Krinjing & 3 & 3 & 1 & 5 & 4 & 16 & Tinggi \\
\hline Mutisari & 2 & 3 & 1 & 4 & 5 & 15 & Tinggi \\
\hline Binangun & 3 & 2 & 1 & 3 & 3 & 12 & Sedang \\
\hline Kalidesel & 4 & 2 & 2 & 1 & 5 & 14 & Sedang \\
\hline Banyukembar & 2 & 2 & 1 & 4 & 4 & 13 & Sedang \\
\hline Pasuruhan & 3 & 2 & 3 & 5 & 4 & 18 & Tinggi \\
\hline Gmw. Kidul & 3 & 2 & 4 & 5 & 4 & 18 & Tinggi \\
\hline Wonosroyo & 5 & 2 & 1 & 3 & 4 & 15 & Tinggi \\
\hline Watumalang & 5 & 2 & 2 & 5 & 4 & 18 & Tinggi \\
\hline
\end{tabular}

Sumber : data primer diolah (2016)

Hasil penilaian menunjukkan hanya satu desa dengan risiko rendah (Limbangan). Risiko rendah berarti pemanfaatan air dari sumber mata air dapat dilakukan berkelanjutan dengan dukungan dari sistem pemantauan dan evaluasi berkala. Hal ini bermakna bahwa pemanfaatan pada desa tersebut telah terkelola dengan baik didukung ketersediaan prasarana dan pola perilaku yang baik dari masyarakat sehingga pemanfaatan tersebut tidak mengkhawatirkan ditinjau dari aspek kesehatan, khususnya pada cemaran koliform.

Hasil pada tabel 5 menunjukkan adanya 6 desa dengan risiko tinggi terhadap pemanfaatan mata air karena koliform, dengan 3 diantaranya dipandang kritis yaitu Pasuruhan, Gumawang Kidul dan Watumalang. Hal ini telah terbukti dengan terjadinya KLB diare di Desa Pasuruhan 
pada 2015. Peristiwa tersebut dimungkinkan sebagai dampak resiko pemanfaatan air baku dari sumber mata air yang tidak terkelola baik kualitasnya. Risiko semakin tinggi mempertimbangkan rasio pemanfaatan yang tinggi pada ketiga desa tersebut.

Kehadiran koliform dalam air baku setidaknya diwaspadai sebagai ancaman atau indikasi penurunan kualitas mikrobiologis pada air. Sampel koliform positif pada air yang semestinya bebas bisa mengindikasikan ketidakefektifan perlakuan, keterbatasan penggunaan desinfektan, intrusi dari air tercemar ke dalam air baku, terjadinya permasalahan pada sistem distribusi yang kesemuanya tidak dapat ditoleransi. Penelitian-penelitian terdahulu mengindikasikan adanya hubungan kuat antara kejadian ledakan waterborne disease dengan pengelolaan koliform pada air (Pal, 2014; Divya and Solomon, 2016).

Indikasi pencemaran koliform berdasarkan penelitian dapat berasal dari limbah domestik terkait berkaitan dengan cemaran feses dan kotoran hewan. Karakteristik wilayah dan perilaku masyarakat di Watumalang menguatkan indikasi tersebut. Watumalang didominasi oleh pemukiman dengan kualitas sanitasi kurang memadai dan rentan risiko pencemaran pada sarana air bersih.

Hasil kuisioner kepemilikan sarana menggambarkan kekurangan lain pada jarak yang tidak ideal antara kandang ternak dengan tampungan air rumah serta kurangnya tempat sampah memadai. Keduanya memudahkan vektor penyakit seperti lalat hinggap dan kemudian memindahkannya pada air tampungan. Bahkan, jarak yang dekat dengan sumber kontaminasi besar akan memungkinkan cemaran langsung dari sumber kontaminan tersebut.

Justifikasi dari rentannya cemaran ternak muncul pada hasil pantauan aspek abiotik yang memunculkan nilai klorida sebagai salah satu parameter yang signifikan pada seluruh sampel air POKMAIR. Cemaran klorida merupakan dapat bersumber dari bahan organik pada aktivitas industri dan peternakan (Venkateshraju, 2010). Keterbatasan industri pada wilayah
Watumalang menjadikan sumber peternakan sebagai kontributor utama cemaran ini. Kondisi ini menunjukkan kerentanan tampungan air pada masyarakat POKMAIR terhadap cemaran limbah peternakan, kemungkinan juga feses ternak. Penelitian yang sama dari Venkateshraju (2010) menghasilkan korelasi positif yang amat kuat antara peningkatan kadar klorida dengan koliform (r 0,85).

Hasil yang terjadi di Watumalang sesuai penelitian dari Windusari dan Sari (2015) tentang cemaran koliform di Sungai Musi yang diakibatkan terutama oleh padatnya pemukiman dengan sanitasi buruk. Nilai koliform akan cenderung meningkat pada lokasi dengan karakter tersebut akibat cemaran kotoran hewan dan manusia. Penelitian cemaran koliform Shariq et al (2016) menyatakan kondisi selaras bahwa adanya pemukiman yang dihuni secara konsisten memiliki kerentanan lebih tinggi pada tercemarnya air oleh koliform akibat sanitasi yang tidak memadai, kurangnya perawatan fasilitasi sanitasi, kurangnya supervisi sumber air dan intensitas rendah pada pemantauan kualitas air baku secara rutin. Resiko akan turut meningkat seiring meningkatnya populasi hunian.

Hasil tersebut dapat menjadi masukan atau rekomendasi bagi pemerintah untuk program peningkatan kualitas air baku POKMAIR di masa mendatang. Hasil-hasil di atas menggambarkan bahwa permasalahan terletak pada ketidakmampuan masyarakat secara mandiri mengelola kualitas airnya. Pemerintah dapat membantu menurunkan pembatas antara persepsi dan perilaku dengan memberikan bantuan bagi pembangunan sarana sanitasi baru yang lebih layak. Hasil penilaian risiko pemanfaatan pada setiap desa menunjukkan lokasi-lokasi yang semestinya memperoleh prioritas dalam perbaikan kualitas air bakunya, khususnya yang bersumber dari mata air.

\section{Simpulan}

Mata air menjadi sumber air baku utama Kecamatan Watumalang (60,66\% penduduk), khususnya POKMAIR. Hasil kajian 
menunjukkan bahwa sebanyak 37,5\% dari total desa di Kecamatan Watumalang menunjukkan pemanfaatan air yang tergolong berisiko tinggi yaitu berdasarkan aspek cemaran koliform, kepemilikan sarana sanitasi, persepsi lingkungan, risiko pencemaran sarana dan rasio pemanfaatan setiap desa. Evaluasi terhadap cemaran koliform menghasilkan data hanya $29 \%$ air baku POKMAIR yang memenuhi persyaratan air bersih. Kajian berdasarkan variabel penelitian menunjukkan bahwa hubungan paling erat terhadap cemaran koliform adalah kepemilikan sarana sanitasi ( $r$-0,381). Adapun pada Kecamatan Watumalang terjadi kecenderungan bahwa persepsi lingkungan yang baik tidak serta merta mempengaruhi perilaku masyarakat terutama dalam pembangunan sanitasi yang layak dan berkualitas (r 0,173).

\section{Daftar Referensi}

Avigliano, E. and Schehone, N.F. 2015. Human Health Risk Assesment and Environmental Distribution of Trace Elements, Glyphosate, Fecal Coliform and Total Coliform in Atlantic Rainforest Mountain Rivers. Microchemical Journal 122 (2015) : 149-158. elsevier.com/ locate/microc (akses 3 Oktober 2016)

Badan Pusat Statistik Kabupaten Wonosobo. 2016. Kecamatan Watumalang dalam Angka 2016.

Butt, I and Ghaffar, A. 2012. Groundwater Quality Assesment Near Mehmood Boti Landfill, Lahore, Pakistan. Asian Journal of Social Sciences and Humanities 1 (2) pp : 13-24

Campbell, J.W., Watson, A., Watson, C., Ball, H., and R. Pirkle. 2011. Eschericia coli, Other Coliform and Environmental Che oheterothropic Bacteria in Isolated Water Pools from Six Caves in Northern Alabama and Northwester Georgia. Journal of Caves and Karst Studies 73 (2) pp : 75-82. DOI : 10.4311/jcks2009mb1031

Colclasure, V.J., Soderquist, T.J., Lynch, T., Schubert, N., McCormick, D.S., Urrutia, E., Knickerbocker, C., McCord, D., and J.H. Kavouras. 2015. Coliform Bacteria, Fabrics and The Environment. American Journal of Infection Control 43 (2015) pp : 154-158. DOI : 10.1016/j.ajic.2014.11.001

Dinas Kesehatan Kabupaten Wonosobo. 2013. Laporan Tahunan Dinas Kesehatn Kabupaten Wonosobo tahun 2013, Bidang PMK Dinas Kesehatan Kabupaten Wonosobo

Divya, A.H and Solomon, P.A. 2016. Effects of Some Water Quality Parameters Especially Total Coliform and Fecal Coliform in Surface Water of Chalakudy River. Procedia Technology 24 (2016) pp : 631-638. DOI : 10.1016/j.protcy.2016.05.151

Megha, P.U., Kavya, P., Murugan, S., and P.S. Harikumar. 2015. Sanitation Mapping on Groundwater Contamination in a Rural Village of India. Journal of Environmetal Protection 2015 (6) pp : 34-44. dx.doi.org/10.4236/jep.2015.61005

Mohsin, M., Safdar, S., Ashgar, F. And F. Jamal. 2013. Assesment of Drinking Water Quality and its Impact on Residents Health in Bahawalpur City. International Journal of Humanities and Social Science Vol 3 (15) : 114-128 August 2013. ijhssnet.com (akses 4 Oktober 2016)

Pal, P. 2014. Detection of coliform in drinking water and its effect on human health - A Review. International Letters of Natural Sciences 17 (2014) : 122-131

Peraturan Menteri Kesehatan Nomor 416/Menkes/Per/IX/1990 tentang Syarat-Syarat dan Pengawasan Kualitas Air

Pujiyati, Setyono, P. dan Wiryanto. 2016. The Provision of Clean Water Contamination Risk and Environment Perception of Water User Groups (POKMAIR) in Watumalang District, 
Wonosobo Regency, Central Java. Proceedings. The $3^{\text {rd }}$ International Conference on Health Science 2016. Yogyakarta. Poltekkes Kemenkes

Sanitasi Total Berbasis Masyarakat (STBM). 2016. Monitoring Data. Laporan Kemajuan Akses Sanitasi Kabupaten Wonosobo. stbm-indonesia.org/monev/ (diakses 10 Oktober 2015).

Shariq, M., Singh, S., Farooq, U., Dhariyal, K.K., Singh, K., and Kaur, N. 2016. Presumptive Coliform Count in Water Sample Collected From Different Sites of A University, Moradabad, Uttar Pradesh, India. International Journal of Scientific Study 3 (12) : 91-96

Soeprobowati, T.R., Tandjung, S.D., Sutikno, Hadisusanto, S., Gell, P., Hadiyanto, and S.W.A. Suedy. 2016. The Water Quality Parameters Controlling Diatoms Assemblage in Rawapening Lake, Indonesia. Biodiversitas 17 (2) : 657-664. DOI : 10.13057/biodiv/d170239

Tong, Y., Yao, R., He, W., Zhou, F., Chen, C., Liu, X., Lu, Y., Zhang, W., Lin, Y., and M. Zhou. 2016. Impacts of Sanitation Upgrading to The Decrease of Fecal Coliform Entering Into The Environmental in China. Environmetal Research 149 (2016) pp : 57-65. DOI : 10.1016/j. envres.2016.05.009

Venkateshraju, K., Ravikumar, P., Somashekar, P., and Prakash, K.L. 2010. Physico-Chemical and Bacteriological Investigation on The River Cauvery of Kollegal Stretch in Karnataka. Kathmandu University Journal of Science Engineering and Technology 6 (1) : 50-59

Windusari, Y dan Sari, N.P. 2015. Kualitas Perairan Sungai Musi di Kota Palembang Sumatera Selatan. Bioeksperimen 1 (1): 1-5 